\title{
2-lodo-N-isopropyl-5-methoxybenzamide as a highly reactive and environmentally benign catalyst for alcohol oxidation
}

\author{
Takayuki Yakura*, Tomoya Fujiwara, Akihiro Yamada and Hisanori Nambu
}

\author{
Full Research Paper \\ Address: \\ Graduate School of Medicine and Pharmaceutical Sciences, \\ University of Toyama, Sugitani, Toyama 930-0194, Japan \\ Email: \\ Takayuki Yakura* - yakura@pha.u-toyama.ac.jp \\ * Corresponding author \\ Keywords: \\ hypervalent iodine; iodobenzamide; organic catalysis; oxidation; \\ oxone
}

\author{
Beilstein J. Org. Chem. 2018, 14, 971-978. \\ doi:10.3762/bjoc. 14.82 \\ Received: 13 February 2018 \\ Accepted: 18 April 2018 \\ Published: 30 April 2018 \\ This article is part of the Thematic Series "Hypervalent iodine chemistry in \\ organic synthesis". \\ Guest Editor: T. Wirth
}

(C) 2018 Yakura et al.; licensee Beilstein-Institut.

License and terms: see end of document.

\begin{abstract}
Several $\mathrm{N}$-isopropyliodobenzamides were evaluated as catalysts for the oxidation of benzhydrol to benzophenone in the presence of Oxone $^{\circledR}\left(2 \mathrm{KHSO}_{5} \cdot \mathrm{KHSO}_{4} \cdot \mathrm{K}_{2} \mathrm{SO}_{4}\right)$ as a co-oxidant at room temperature. A study on the substituent effect of the benzene ring of $\mathrm{N}$-isopropyl-2-iodobenzamide on the oxidation revealed that its reactivity increased in the following order of substitution: $5-\mathrm{NO}_{2}<5-\mathrm{CO}_{2} \mathrm{Me}, 3-\mathrm{OMe}<5-\mathrm{OAc}<5-\mathrm{Cl}<\mathrm{H}, 4-\mathrm{OMe}<5-\mathrm{Me}<5-\mathrm{OMe}$. The oxidation of various benzylic and aliphatic alcohols using a catalytic amount of the most reactive 5-methoxy derivative successfully resulted in moderate to excellent yields of the corresponding carbonyl compounds. The high reactivity of the 5-methoxy derivative at room temperature is a result of the rapid generation of the pentavalent species from the trivalent species during the reaction. 5-Methoxy-2-iodobenzamide would be an efficient and environmentally benign catalyst for the oxidation of alcohols, especially benzylic alcohols.
\end{abstract}

\section{Introduction}

The development of an efficient and environmentally benign organic synthesis is required for minimizing material use, energy consumption, and environmental pollution in the production of both bulk and fine chemicals. Oxidation is a fundamental and frequently used transformation in organic synthesis. Heavy metal-based oxidants such as chromium(VI), lead(IV), and mercury(II) have been extensively used for this purpose for a long time. However, these oxidants are highly toxic and produce hazardous waste. Recently, hypervalent iodine oxidants have been widely employed for oxidation in organic synthesis [1-9] because they are nonmetallic, less toxic, and easy to handle, and they allow mild reaction conditions in most cases. Pentavalent iodine reagents such as Dess-Martin periodinane (DMP, 1) [10] and 2-iodoxybenzoic acid (IBX, 2) [11] are well known as representative environmentally benign oxidants for alcohol oxidation (Figure 1). However, despite the utility and 
<smiles></smiles><smiles>O=C1OI(=O)(O)c2ccccc21</smiles><smiles>CC(C)(COc1ccc(I)c(C(=O)O)c1)C(F)(F)F</smiles>

7<smiles>O=C(O)c1ccccc1I</smiles><smiles>[R]c1c([R])c([R])c(C(=O)O)c(I)c1[R]</smiles>

4: $R^{1}, R^{2}=M e$ 5: $\mathrm{R}^{1}=\mathrm{H}, \mathrm{R}^{2}=t-\mathrm{Bu}$<smiles>COc1cc(C(=O)O)c(I)c(OC)c1-c1c(OC)cc(C(=O)O)c(I)c1OC</smiles><smiles>O=S(=O)(O)c1ccc(I)cc1</smiles>

12

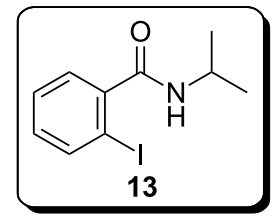

8: $R^{3}, R^{4}=H$
9: $R^{3}=M e, R^{4}=H$

10: $R^{3}, R^{4}=M e$

11: $R^{3}=O M e, R^{4}=H$

Figure 1: Structures of pentavalent iodine oxidants $\mathbf{1}$ and $\mathbf{2}$, and iodine catalysts $\mathbf{3 - 1 3 .}$

versatility of these oxidants, they still have several drawbacks: both are potentially explosive, DMP is moisture-sensitive, and IBX is insoluble in common organic solvents. To overcome these drawbacks, IBX analogs [12-22] and several iodoxyarene derivatives [23-38] have been developed, and the stabilization of IBX by combining it with benzoic and isophthalic acids (SIBX) [39] has been reported. Nevertheless, from a green chemistry viewpoint, pentavalent iodine oxidants are not ideal because oxidation reactions require a stoichiometric amount of the oxidant that produces an equimolar amount of organoiodine waste. The catalytic use of pentavalent iodine species is an effective method for reducing the use of iodine compounds and the produced waste [40-44]. 2-Iodobenzoic acid (3) [45,46] and its derivatives such as 4-7 [20,47-51] and 2-iodobenzenesulfonic acid (8) and its derivatives 9-11 [52-57] have been developed as catalysts for the oxidation of alcohols in the presence of Oxone ${ }^{\circledR}\left(2 \mathrm{KHSO}_{5} \cdot \mathrm{KHSO}_{4} \cdot \mathrm{K}_{2} \mathrm{SO}_{4}\right)$ as a co-oxidant. In these reported systems, high temperatures $\left(40-70{ }^{\circ} \mathrm{C}\right)$ are often required to generate potentially explosive pentavalent iodine compounds in situ except for the reactions involving multisubstituted benzoic acids and benzenesulfonic acid (4-6 and 10) which can be performed at room temperature [20,48-51,57]. In contrast, the use of a combination of a catalytic amount of $\mathrm{RuCl}_{3}$ and a stoichiometric amount of Oxone ${ }^{\circledR}$ as the co-oxidation system does not require heating despite the use of iodobenzene and 4-iodobenzenesulfonic acid (12) as catalysts $[58,59]$. As part of our study on the development of multifunctionalized organocatalysts based on hypervalent iodine chemistry [60-66], we found that $N$-isopropyl-2-iodobenzamide (13), when utilized as a catalyst with Oxone ${ }^{\circledR}$ at room temperature, appears to be a promising catalyst for efficient and environmentally benign alcohol oxidation reactions [67]. Herein, we report our efforts on improving the reactivity of 2-iodobenzamide catalysts.

\section{Results and Discussion}

We evaluated several 2-iodobenzoic acid derivatives including esters and amides as catalysts for alcohol oxidation in the presence of Oxone ${ }^{\circledR}$, and we found that the simply modified derivative, $N$-isopropylamide 13 , exhibited excellent catalytic properties at room temperature [67]. Interestingly, the reactivity of $\mathbf{1 3}$ was much higher than that of $\mathbf{3}$ at room temperature but was lower at $70{ }^{\circ} \mathrm{C}$. However, the reactivity of $\mathbf{1 3}$ itself was not so high: the oxidation of benzhydrol (14a) with 0.3 equiv of 13, 2.5 equiv of Oxone ${ }^{\circledR}$, and 1 equiv of $\mathrm{Bu}_{4} \mathrm{NHSO}_{4}$ in $\mathrm{MeNO}_{2} / \mathrm{H}_{2} \mathrm{O}(8: 3)$ completed in $12 \mathrm{~h}$ at room temperature $\left(25^{\circ} \mathrm{C}\right)$ to produce a $98 \%$ yield of benzophenone (15a, Table 1 , entry 1) [67]. Therefore, enhancement of the reactivity of the catalyst was desired for practical use. To develop a more reactive catalyst, we evaluated several types of $\mathrm{N}$-isopropyliodobenzamides (Table 1). Although most of the previously reported iodoarene catalysts based on pentavalent iodine compounds have a carboxyl or sulfoxyl group at the ortho-position to the iodine atom, Zhdankin and colleagues reported that both 2-iodobenzenesulfonic acid (8) and 4-iodobenzensulfonic acid (12) exhibited high reactivity in their $\mathrm{RuCl}_{3}-\mathrm{Oxone}{ }^{\circledR}$ co-oxidant system $[58,59]$. Therefore, we expected that the reactivity of 4-iodobenzamide $\mathbf{1 6}$ (Figure 2) would be similar to that of 13. However, the oxidation of $14 a$ with 16 under the above conditions did not complete even after $24 \mathrm{~h}$, and the yield of 15a and of recovered 14a was $30 \%$ and $67 \%$, respectively (Table 1, entry 2). These results indicate that the reactivity of the iodobenzamides depends on the ortho-relationship of the iodine atom to the amide group. Therefore, we then investigated $\mathrm{N}$-isopropyl-2-iodobenzamides that have an additional functional group on the benzene ring. Based on the results of our studies on phenol oxidation $[60,62]$ and Ishihara's [52] and Moorthy's [20,48] studies on alcohol oxidation, an electron-donating group at the para-position to the iodine should be ex- 
Table 1: Oxidation of benzhydrol (14a) to benzophenone (15a) catalyzed by 13 and $16-25$.

\begin{tabular}{|c|c|c|c|c|}
\hline \multirow[b]{2}{*}{ entry $^{a}$} & \multicolumn{3}{|c|}{$\begin{array}{c}\text { iodoarene ( } 0.3 \text { equiv }) \\
\text { Oxone }{ }^{\circledR}(2.5 \text { equiv }) \\
\mathrm{Bu}_{4} \mathrm{NHSO}_{4}(1.0 \text { equiv })\end{array}$} & \multirow[b]{2}{*}{ recovery of $14 a(\%)^{b}$} \\
\hline & iodobenzamide & time (h) & yield $(\%)^{b}$ & \\
\hline $1^{\mathrm{c}}$ & 13 & 12 & 98 & - \\
\hline 2 & 16 & 24 & 30 & 67 \\
\hline 3 & 17 & 6 & 97 & - \\
\hline 4 & 18 & 10 & 98 & - \\
\hline 5 & 19 & 18 & 98 & - \\
\hline 6 & 20 & 19 & 98 & - \\
\hline 7 & 21 & 23 & 96 & - \\
\hline 8 & 22 & 46 & 98 & - \\
\hline 9 & 23 & 48 & 23 & 75 \\
\hline 10 & 24 & 13 & 98 & - \\
\hline 11 & 25 & 23 & 99 & - \\
\hline
\end{tabular}

aAll reactions were performed on a $0.5 \mathrm{mmol}$ scale. ${ }^{b} /$ solated yield. ${ }^{\mathrm{C}}$ Ref. [67]

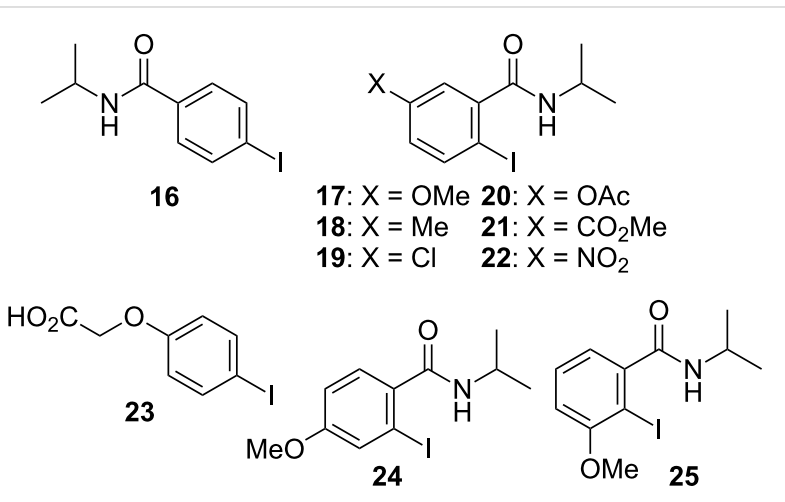

Figure 2: Structures of the catalysts $16-25$.

pected to enhance the reactivity of iodoarene catalysts. The investigation began with the 5 -substituted 2 -iodobenzamides 17-22 (Figure 2). Oxidation of 14a with 5-methoxy-2-iodobenzamide 17 was much faster than that with $\mathbf{1 3}$ and was completed within $6 \mathrm{~h}$ to produce 15a in 97\% yield (Table 1, entry 3 ). The 5-methyl derivative $\mathbf{1 8}$ exhibited a slightly higher reactivity than $\mathbf{1 3}$ (Table 1, entry 4). The introduction of an electron-withdrawing group such as a chloro, acetoxy, methoxycarbonyl, or nitro group at the 5-position led to a decrease in reactivity (Table 1 , entries 5-8). These results are in good agreement with the reported studies $[20,48,52,60,62]$. To confirm the importance of the electron-withdrawing carboxyamide group at the ortho-position, we examined the oxidation of 14a with 4-iodophenoxyacetic acid (23); the results showed excellent reactivity for phenol oxidations [60-64].
When $\mathbf{1 4 a}$ was oxidized with $\mathbf{2 3}$, the reaction was very slow and yielded only $23 \%$ of $15 \mathbf{a}$ and $75 \%$ of recovered $14 \mathbf{a}$ even after $48 \mathrm{~h}$ (Table 1, entry 9) [68]. Since the 5-methoxy derivative 17 was the most reactive, we then investigated the reactivities of 24 and 25, which have methoxy groups at the meta- and orthopositions to the iodine atom, and found that 4-methoxyamide $\mathbf{2 4}$ exhibited the same reactivity as nonsubstituted $\mathbf{1 3}$ (Table 1, entry 10). On the other hand, oxidation with 3-methoxyamide $\mathbf{2 5}$ was much slower than that with $\mathbf{1 3}$ and needed $23 \mathrm{~h}$ to complete (Table 1, entry 11). Although the ortho- and the paramethoxy groups should show a similar electronic effect on the iodine atom, the lower reactivity of $\mathbf{2 5}$ might be explained by the steric hindrance around the iodine atom of $\mathbf{2 5}$. Consequently, the reactivities of the 2-iodobenzamides 17-22, 24, and 25 decreased in the following order of substitution: 5-OMe (17) $>5$ - Me (18) > H (13), 4-OMe (24) > 5-Cl (19) > $5-\mathrm{OAc}(\mathbf{2 0})>5-\mathrm{CO}_{2} \mathrm{Me}(\mathbf{2 1}), 3-\mathrm{OMe}(\mathbf{2 5})>5-\mathrm{NO}_{2}(\mathbf{2 2})$.

With a highly reactive catalyst in hand, we examined the oxidation of various secondary alcohols $\mathbf{1 4 b}-\mathbf{f}$ and primary alcohols $\mathbf{1 4} \mathbf{g}-\mathbf{k}$ with 0.3 equiv of $\mathbf{1 7}$ in the presence of 2.5 equiv of Oxone ${ }^{\circledR}$ and 1 equiv of $\mathrm{Bu}_{4} \mathrm{NHSO}_{4}$ in an 8:3 mixture of $\mathrm{MeNO}_{2}$ and water at room temperature. These results as well as those obtained from a similar oxidation using $\mathbf{1 3}$ as a catalyst are summarized in Table 2. The secondary benzylic alcohols 14b-e were oxidized with 17 in much shorter reaction times than those oxidized with $\mathbf{1 3}$ to give the corresponding ketones $\mathbf{1 5 b}-\mathbf{e}$ in good to excellent yields (Table 2, entries 1-4). Oxidation of the aliphatic secondary alcohol $\mathbf{1 4 f}$ with $\mathbf{1 7}$ required a 
Table 2: Oxidation of various alcohols $14 b-k$ with $17 .^{a}$

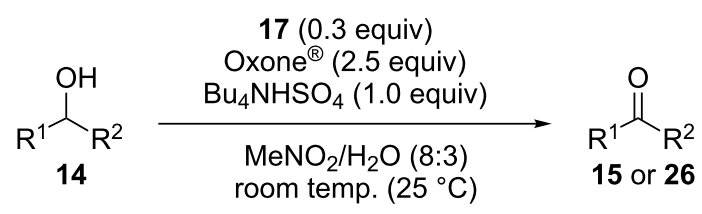

entry alcohol

14b

2<smiles>OC1CCc2ccccc21</smiles>

3<smiles>CC(O)c1ccccc1</smiles>

4<smiles>OC(Cc1ccccc1)c1ccccc1</smiles>

$14 \mathrm{e}$

5<smiles>CC(O)CCc1ccccc1</smiles>

$14 f$

6<smiles>O=[N+]([O-])c1ccc(CO)cc1</smiles>

7<smiles>OCc1ccc(Cl)cc1</smiles>

8<smiles>CC(=O)c1ccc(CO)cc1</smiles>

9<smiles>OCCCc1ccccc1</smiles>

$14 j$ carbonyl compound<smiles>O=C(c1ccc(F)cc1)c1ccc(F)cc1</smiles>

15b<smiles>O=C1CCc2ccccc21</smiles>

7 (17) $86(71)$<smiles>CC(=O)c1ccccc1</smiles>

15d<smiles>O=C(Cc1ccccc1)c1ccccc1</smiles>

$10(20)$ 98 (97)

$15 \mathrm{e}$<smiles>CC(=O)CCc1ccccc1</smiles>

$15 f$<smiles>O=C(O)c1ccc([N+](=O)[O-])cc1</smiles>

$10(20)$ 89 (82)<smiles>O=C(O)c1ccc(Cl)cc1</smiles>

24 (24) $83(74)$

26h<smiles>CC(=O)c1ccc(C(=O)O)cc1</smiles>

$16(16)$ 96 (89)

26i<smiles>O=C(O)CCc1ccccc1</smiles>

$9(20)$ 85 (90)

26j 
Table 2: Oxidation of various alcohols $14 b-k$ with $17 .^{\text {a }}$ (continued)

10<smiles>OCC1CCCCC1</smiles>

$14 \mathrm{k}$<smiles>O=C(O)C1CCCCC1</smiles>

$26 \mathrm{k}$
$36(36)$

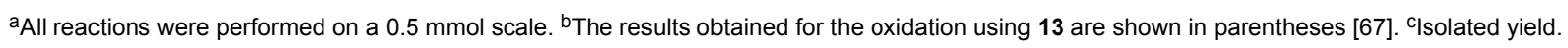

slightly longer reaction time than that with 13 (Table 2, entry 5). The primary alcohols $\mathbf{1 4} \mathbf{g}-\mathbf{k}$ were converted into the corresponding carboxylic acids $\mathbf{2 6} \mathbf{g}-\mathbf{k}$ in moderate to excellent yields (Table 2, entries 6-10). However, the reaction times of the oxidations of $14 \mathbf{h}, \mathbf{1 4} \mathbf{i}$, and $14 \mathbf{k}$ with 17 were similar to those involving 13. These results may be due to the slow oxidation of the aldehydes to carboxylic acids [69]. The catalyst 17 was stable under the oxidation conditions and it was recovered in $67-92 \%$ after reductive treatment.

The next objective was to investigate the oxidation mechanism of 2-iodobenzamide catalysts. Zhdankin and colleagues reported the oxidation of alcohols to their corresponding carbonyl compounds using several 2-iodoxybenzamides [23]. Therefore, we tried to confirm the formation of 2-iodoxybenzamide 29 from 2-iodobenzamide $\mathbf{1 7}$ in an oxidation reaction (Scheme 1). Iodoarene 17 was treated with 2.5 equiv of Oxone ${ }^{\circledR}$ and 1 equiv of $\mathrm{Bu}_{4} \mathrm{NHSO}_{4}$ in a 4:1 mixture of acetonitrile- $d_{3}$ and $\mathrm{D}_{2} \mathrm{O}$ at a low concentration $(0.01 \mathrm{M})$ at room temperature, and the reaction was monitored by ${ }^{1} \mathrm{H}$ NMR spectroscopy. The reaction profiles for $\mathbf{1 7}$ as well as for 2-iodobenzoic acid (3) are summarized in Figure 3. In the reaction involving 17, the

$$
\begin{aligned}
& \text { (1) } \\
& \text { 27: } \mathrm{X}=\mathrm{OMe} \\
& \mathrm{R}=\mathrm{NH}-\mathrm{iPr} \\
& \underbrace{P}_{1} \\
& \text { Oxone }{ }^{\circledR} \text { (2.5 equiv) } \\
& \text { 28: } X=H \\
& \mathrm{Bu}_{4} \mathrm{NHSO}_{4} \text { (1.0 equiv) } \mathrm{R}=\mathrm{OH} \\
& \text { 17: } \mathrm{X}=\mathrm{OMe} \\
& \mathrm{R}=\mathrm{NH}-\mathrm{iPr} \\
& \text { 3: } \mathrm{X}=\mathrm{H} \\
& \mathrm{R}=\mathrm{OH} \\
& \mathrm{R}=\mathrm{NH}-\mathrm{iPr} \\
& \text { 2: } \mathrm{X}=\mathrm{H} \\
& \mathrm{R}=\mathrm{OH}
\end{aligned}
$$

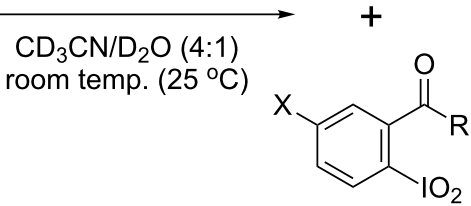

Scheme 1: Oxidation of the monovalent iodine derivatives 17 and 3 to the pentavalent iodine derivatives 29 and 2 using Oxone ${ }^{\circledR}$.
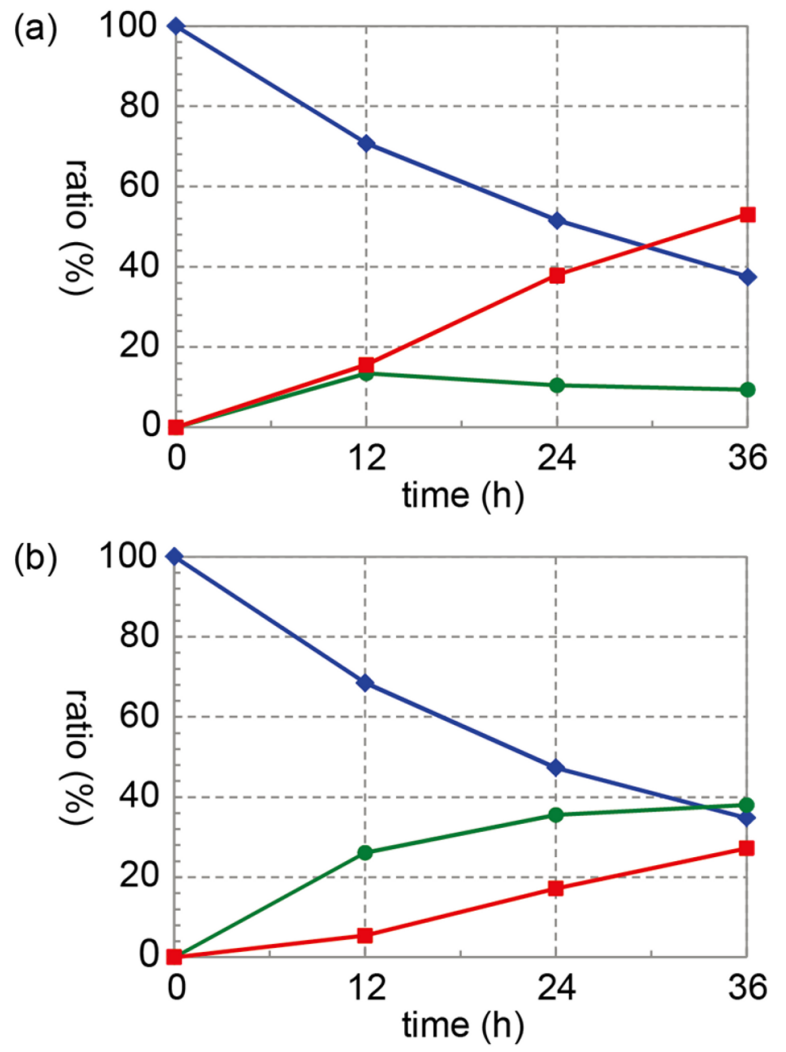

Figure 3: Reaction profile of the oxidation of (a) iodobenzamide 17 and (b) 2-iodobenzoic acid (3) with Oxone ${ }^{\circledR}$ in the presence of $\mathrm{Bu}_{4} \mathrm{NHSO}_{4}$ in a $4: 1$ mixture of $\mathrm{CD}_{3} \mathrm{CN}$ and $\mathrm{D}_{2} \mathrm{O}$ : monovalent iodine derivatives 17 and 3 (blue), trivalent iodine derivatives 27 and 28 (green), and pentavalent iodine derivatives 29 and 2 (red).

amount of pentavalent iodine derivative $\mathbf{2 9}$ gradually increased with a decrease in the amount of $\mathbf{1 7}$ and only a small amount of trivalent iodine derivative 27 was observed during the reaction. The ratio of $\mathbf{1 7}$ to trivalent $\mathbf{2 7}$ and pentavalent 29 was determined to be 38:9:53 after $36 \mathrm{~h}$. In the oxidation of $\mathbf{3}$, monovalent 3 was consumed at almost the same rate as the oxidation of 17. However, the formation of pentavalent 2 was much slower than that of 29, and a considerable amount of trivalent $\mathbf{2 8}$ remained during the reaction. After $36 \mathrm{~h}$, the oxidation of 3 generated $27 \%$ of $\mathbf{2}$ with $35 \%$ unreacted $\mathbf{3}$ and $38 \%$ trivalent $\mathbf{2 8}$. Thus, it is clear that the pentavalent iodine species $\mathbf{2}$ and $\mathbf{2 9}$ 
were generated during the oxidation reactions of monovalent 3 and $\mathbf{1 7}$ and that the oxidation of trivalent $\mathbf{2 7}$ to pentavalent $\mathbf{2 9}$ is much faster than that of $\mathbf{2 8}$ to $\mathbf{2}$ at room temperature. These results also suggest that the formation of the pentavalent iodine species from the corresponding trivalent iodine species might be the rate-determining step in the catalytic hypervalent iodine oxidation of 17 [70].

On the basis of the above results, a plausible mechanism for the oxidation catalyzed by the 2-iodobenzamides is shown in Scheme 2. Iodobenzamide $\mathbf{A}$ is readily oxidized by tetra- $n$ butylammonium peroxymonosulfate $\left(\mathrm{Bu}_{4} \mathrm{NHSO}_{5}, \mathbf{3 0}\right)$, which is derived from $\mathrm{Bu}_{4} \mathrm{NHSO}_{4}$ and Oxone ${ }^{\circledR}$, to pentavalent iodine species $\mathbf{C}$ at room temperature. The resultant $\mathbf{C}$ oxidizes alcohol $\mathbf{1 4}$ to ketone $\mathbf{1 5}$ or aldehyde $\mathbf{3 1}$ during its reduction to trivalent iodine B. Aldehyde $\mathbf{3 1}$ is further oxidized with $\mathbf{3 0}$ with the assistance of $\mathbf{A}$ or $\mathbf{C}$ [67] to give carboxylic acid 26. Iodine $\mathbf{B}$ is re-oxidized with $\mathbf{3 0}$ to regenerate $\mathbf{C}$. The oxidation proceeds at room temperature because of the fast oxidation of trivalent $\mathbf{B}$ to pentavalent $\mathbf{C}$.

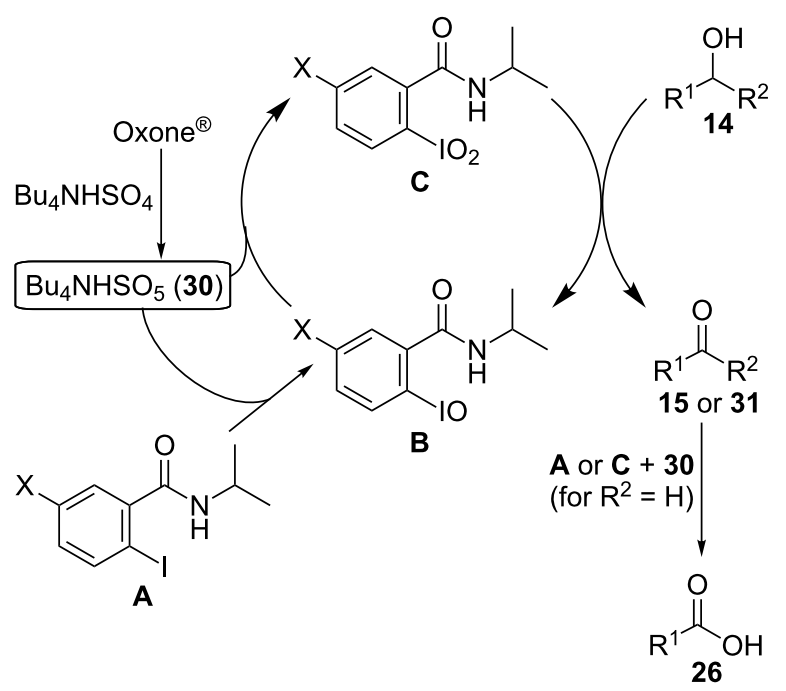

Scheme 2: Plausible reaction mechanism for the oxidation of alcohols catalyzed by the 2-iodobenzamides.

\section{Conclusion}

In summary, we have developed 2-iodo- $N$-isopropyl-5methoxybenzamide (17) as an efficient catalyst for the oxidation of primary and secondary alcohols. The reaction of benzylic and aliphatic alcohols $\mathbf{1 4}$ with a catalytic amount of $\mathbf{1 7}$ in the presence of Oxone ${ }^{\circledR}$ and $\mathrm{Bu}_{4} \mathrm{NHSO}_{4}$ at room temperature proceeded smoothly to provide good to excellent yields of the corresponding carbonyl compounds $\mathbf{1 5}$ and $\mathbf{2 6}$. The higher reactivity of $\mathbf{1 7}$ at room temperature results from the rapid oxidation of trivalent iodine compound $\mathbf{2 7}$ to the pentavalent com- pound 29. 5-Methoxy-2-iodobenzamide 17 promises to be an efficient and environmentally benign catalyst for oxidation of alcohol, especially benzylic alcohols.

\section{Experimental}

Typical experimental procedure for the oxidation of secondary alcohols 14a-f: Secondary alcohol $14(0.50 \mathrm{mmol})$ was added to a solution of the catalyst $(0.15 \mathrm{mmol})$ and $\mathrm{Bu}_{4} \mathrm{NHSO}_{4}$ $(170 \mathrm{mg}, 0.50 \mathrm{mmol})$ in a mixture of $\mathrm{MeNO}_{2}(1.6 \mathrm{~mL})$ and water $(0.6 \mathrm{~mL})$, followed by Oxone ${ }^{\circledR}(768 \mathrm{mg}, 1.25 \mathrm{mmol})$ at room temperature $\left(25^{\circ} \mathrm{C}\right)$. After 14 was completely consumed, as indicated by TLC, the resulting mixture was diluted using EtOAc and was washed with water. The organic layer was then washed with saturated aqueous $\mathrm{Na}_{2} \mathrm{~S}_{2} \mathrm{O}_{3}$ and saturated aqueous $\mathrm{NaHCO}_{3}$, dried over $\mathrm{MgSO}_{4}$, filtered, and concentrated under reduced pressure. The residue was purified by silica gel column chromatography to give pure ketone $\mathbf{1 5}$ and the catalyst.

Typical experimental procedure for the oxidation of primary alcohols 14g-k: Primary alcohol $14(0.50 \mathrm{mmol})$ was added to a solution of the catalyst $(0.15 \mathrm{mmol})$ and $\mathrm{Bu}_{4} \mathrm{NHSO}_{4}$ $(170 \mathrm{mg}, 0.50 \mathrm{mmol})$ in a mixture of $\mathrm{MeNO}_{2}(1.6 \mathrm{~mL})$ and water $(0.6 \mathrm{~mL})$, followed by Oxone ${ }^{\circledR}(768 \mathrm{mg}, 1.25 \mathrm{mmol})$ at room temperature $\left(25^{\circ} \mathrm{C}\right)$. After 14 was completely consumed, as indicated by TLC, the resulting mixture was diluted with EtOAc, water, and saturated aqueous $\mathrm{Na}_{2} \mathrm{~S}_{2} \mathrm{O}_{3}$. The organic layer was then washed with saturated aqueous $\mathrm{Na}_{2} \mathrm{~S}_{2} \mathrm{O}_{3}$, saturated aqueous $\mathrm{NaHCO}_{3}$, and brine, dried over $\mathrm{MgSO}_{4}$, filtered, and concentrated under reduced pressure. The residue was purified by silica gel column chromatography to give the catalyst. The combined aqueous layers were acidified with $10 \% \mathrm{HCl}$ and extracted with EtOAc. The organic layer was washed with brine, dried over $\mathrm{MgSO}_{4}$, filtered, and concentrated under reduced pressure. The residue was purified by silica gel column chromatography to give pure carboxylic acid $\mathbf{2 6}$.

\section{Supporting Information}

\section{Supporting Information File 1}

Experimental details and the ${ }^{1} \mathrm{H}$ and ${ }^{13} \mathrm{C}$ NMR spectra of the catalysts, the substrates, and the products.

[https://www.beilstein-journals.org/bjoc/content/ supplementary/1860-5397-14-82-S1.pdf]

\section{Acknowledgments}

This research was partially supported by a Grant-in-Aid for Scientific Research on Innovative Areas "Advanced Molecular Transformations by Organocatalysts" from the Ministry of Education, Culture, Sports, Science and Technology, Japan; JSPS Core-to-Core Program, B. Asia-Africa Science Platforms; 
and Toyama Prefecture Citizens' Personal Development Foundation (TPCPDF).

\section{References}

1. Stang, P. J.; Zhdankin, V. V. Chem. Rev. 1996, 96, 1123-1178. doi:10.1021/cr940424+

2. Zhdankin, V. V.; Stang, P. J. Chem. Rev. 2002, 102, 2523-2584. doi:10.1021/cr010003+

3. Tohma, H.; Kita, Y. Adv. Synth. Catal. 2004, 346, 111-124. doi:10.1002/adsc.200303203

4. Ladziata, U.; Zhdankin, V. V. ARKIVOC 2006, No. ix, 26-58. doi:10.3998/ark.5550190.0007.903

5. Zhdankin, V. V.; Stang, P. J. Chem. Rev. 2008, 108, 5299-5358. doi:10.1021/cr800332c

6. Zhdankin, V. V. J. Org. Chem. 2011, 76, 1185-1197. doi:10.1021/jo1024738

7. Zhdankin, V. V. Hypervalent lodine Chemistry: Preparation, Structure, and Synthetic Applications of Polyvalent lodine Compounds; John Wiley \& Sons, Ltd, 2013. doi:10.1002/9781118341155

8. Kaiho, T., Ed. lodine Chemistry and Applications; John Wiley \& Sons, Ltd, 2014. doi:10.1002/9781118909911

9. Yoshimura, A.; Zhdankin, V. V. Chem. Rev. 2016, 116, 3328-3435. doi:10.1021/acs.chemrev.5b00547

10. Dess, D. B.; Martin, J. C. J. Org. Chem. 1983, 48, 4155-4156. doi:10.1021/jo00170a070

11. Hartmann, C.; Mayer, V. Chem. Ber. 1893, 26, 1727-1732. doi:10.1002/cber.189302602109

12. Dess, D. B.; Martin, J. C. J. Am. Chem. Soc. 1991, 113, 7277-7287. doi:10.1021/ja00019a027

13. Stickley, S. H.; Martin, J. C. Tetrahedron Lett. 1995, 36, 9117-9120. doi:10.1016/0040-4039(95)01978-Q

14. Thottumkara, A. P.; Vinod, T. K. Tetrahedron Lett. 2002, 43, 569-572. doi:10.1016/S0040-4039(01)02217-1

15. Richardson, R. D.; Zayed, J. M.; Altermann, S.; Smith, D.; Wirth, T. Angew. Chem., Int. Ed. 2007, 46, 6529-6532. doi:10.1002/anie.200702313

16. Moorthy, J. N.; Singhal, N.; Senapati, K. Tetrahedron Lett. 2008, 49, 80-84. doi:10.1016/j.tetlet.2007.11.013

17. Kommreddy, A.; Bowsher, M. S.; Gunna, M. R.; Botha, K.; Vinod, T. K. Tetrahedron Lett. 2008, 49, 4378-4382. doi:10.1016/j.tetlet.2008.05.017

18. Moorthy, J. N.; Senapati, K.; Parida, K. N. J. Org. Chem. 2010, 75, 8416-8421. doi:10.1021/jo101639j

19. Cui, L.-Q.; Dong, Z.-L.; Liu, K.; Zhang, C. Org. Lett. 2011, 13, 6488-6491. doi:10.1021/ol202777h

20. Moorthy, J. N.; Senapati, K.; Parida, K. N.; Jhulki, S.; Sooraj, K.; Nair, N. N. J. Org. Chem. 2011, 76, 9593-9601. doi:10.1021/jo201491q

21. Harschneck, T.; Hummel, S.; Kirsch, S. F.; Klahn, P. Chem. - Eur. J. 2012, 18, 1187-1193. doi:10.1002/chem.201102680

22. Yusubov, M. S.; Postnikov, P. S.; Yusubova, R. Y.; Yoshimura, A.; Jürjens, G.; Kirschning, A.; Zhdankin, V. V. Adv. Synth. Catal. 2017, 359, 3207-3216. doi:10.1002/adsc.201700776

23. Zhdankin, V. V.; Koposov, A. Y.; Netzel, B. C.; Yashin, N. V.; Rempel, B. P.; Ferguson, M. J.; Tykwinski, R. R. Angew. Chem., Int. Ed. 2003, 42, 2194-2196. doi:10.1002/anie.200351018
24. Zhdankin, V. V.; Litvinov, D. N.; Koposov, A. Y.; Luu, T.; Ferguson, M. J.; McDonald, R.; Tykwinski, R. R. Chem. Commun. 2004, 106-107. doi:10.1039/b312961f

25. Koposov, A. Y.; Litvinov, D. N.; Zhdankin, V. V. Tetrahedron Lett. 2004, 45, 2719-2721. doi:10.1016/j.tetlet.2004.02.053

26. Zhdankin, V. V.; Goncharenko, R. N.; Litvinov, D. N.; Koposov, A. Y. ARKIVOC 2005, No. iv, 8-18. doi:10.3998/ark.5550190.0006.402

27. Koposov, A. Y.; Nemykin, V. N.; Zhdankin, V. V. New J. Chem. 2005, 29, 998-1000. doi:10.1039/b506573a

28. Kuhakarn, C.; Kittigowittana, K.; Pohmakotr, M.; Reutrakul, V. ARKIVOC 2005, No. i, 143-153. doi:10.3998/ark.5550190.0006.115

29. Zhdankin, V. V.; Koposov, A. Y.; Litvinov, D. N.; Ferguson, M. J.; McDonald, R.; Luu, T.; Tykwinski, R. R. J. Org. Chem. 2005, 70, 6484-6491. doi:10.1021/jo051010r

30. Ladziata, U.; Koposov, A. Y.; Lo, K. Y.; Willging, J.; Nemykin, V. N.; Zhdankin, V. V. Angew. Chem., Int. Ed. 2005, 44, 7127-7131. doi:10.1002/anie.200502707

31. Ladziata, U.; Carlson, J.; Zhdankin, V. V. Tetrahedron Lett. 2006, 47, 6301-6304. doi:10.1016/j.tetlet.2006.06.103

32. Koposov, A. Y.; Karimov, R. R.; Geraskin, I. M.; Nemykin, V. N.; Zhdankin, V. V. J. Org. Chem. 2006, 71, 8452-8458. doi:10.1021/jo0614947

33. Boppisetti, J. K.; Birman, V. B. Org. Lett. 2009, 11, 1221-1223. doi:10.1021/ol8029092

34. Mailyan, A. K.; Geraskin, I. M.; Nemykin, V. N.; Zhdankin, V. V. J. Org. Chem. 2009, 74, 8444-8447. doi:10.1021/jo901638f

35. Altermann, S. M.; Schäfer, S.; Wirth, T. Tetrahedron 2010, 66, 5902-5907. doi:10.1016/j.tet.2010.05.079

36. Yoshimura, A.; Banek, C. T.; Yusubov, M. S.; Nemykin, V. N.; Zhdankin, V. V. J. Org. Chem. 2011, 76, 3812-3819. doi:10.1021/jo200163m

37. Yoshida, Y.; Magara, A.; Mino, T.; Sakamoto, M. Tetrahedron Lett. 2016, 57, 5103-5107. doi:10.1016/j.tetlet.2016.10.016

38. Yoshimura, A.; Yusubov, M. S.; Zhdankin, V. V. Org. Biomol. Chem. 2016, 14, 4771-4781. doi:10.1039/C6OB00773B

39. Ozanne, A.; Pouységu, L.; Depernet, D.; François, B.; Quideau, S. Org. Lett. 2003, 5, 2903-2906. doi:10.1021/ol0349965

40. Richardson, R. D.; Wirth, T. Angew. Chem., Int. Ed. 2006, 45, 4402-4404. doi:10.1002/anie.200601817

41. Ochiai, M.; Miyamoto, K. Eur. J. Org. Chem. 2008, 4229-4239. doi:10.1002/ejoc.200800416

42. Dohi, T.; Kita, Y. Chem. Commun. 2009, 2073-2085. doi:10.1039/b821747e

43. Uyanik, M.; Ishihara, K. Chem. Commun. 2009, 2086-2099. doi:10.1039/b823399c

44. Singh, F. V.; Wirth, T. Chem. - Asian J. 2014, 9, 950-971. doi:10.1002/asia.201301582

45. Thottumkara, A. P.; Bowsher, M. S.; Vinod, T. K. Org. Lett. 2005, 7, 2933-2936. doi:10.1021/ol050875o

46. Schulze, A.; Giannis, A. Synthesis 2006, 257-260. doi:10.1055/s-2005-924764

47. Miura, T.; Nakashima, K.; Tada, N.; Itoh, A. Chem. Commun. 2011, 47, 1875-1877. doi:10.1039/C0CC03149F

48. Seth, S.; Jhulki, S.; Moorthy, J. N. Eur. J. Org. Chem. 2013, 2445-2452. doi:10.1002/ejoc.201201699

49. Jhulki, S.; Seth, S.; Mondal, M.; Moorthy, J. N. Tetrahedron 2014, 70, 2286-2293. doi:10.1016/j.tet.2014.01.034

50. Moorthy, J. N.; Parida, K. N. J. Org. Chem. 2014, 79, 11431-11439. doi:10.1021/jo502002w 
51. Mishra, A. K.; Moorthy, J. N. Org. Chem. Front. 2017, 4, 343-349. doi:10.1039/C6Q000588H

52. Uyanik, M.; Akakura, M.; Ishihara, K. J. Am. Chem. Soc. 2009, 131, 251-262. doi:10.1021/ja807110n

53. Uyanik, M.; Fukatsu, R.; Ishihara, K. Org. Lett. 2009, 11, 3470-3473. doi:10.1021/ol9013188

54. Uyanik, M.; Ishihara, K. Aldrichimica Acta 2010, 43, 83-91.

55. Uyanik, M.; Mutsuga, T.; Ishihara, K. Molecules 2012, 17, 8604-8616. doi:10.3390/molecules17078604

56. Uyanik, M.; Ishihara, K. Org. Synth. 2012, 89, 105-114. doi:10.15227/orgsyn.089.0105

57. Uyanik, M.; Mutsuga, T.; Ishihara, K. Angew. Chem., Int. Ed. 2017, 56, 3956-3960. doi:10.1002/anie.201612463

58. Yusubov, M. S.; Zagulyaeva, A. A.; Zhdankin, V. V. Chem. - Eur. J. 2009, 15, 11091-11094. doi:10.1002/chem.200901953

59. Yusubov, M. S.; Nemykin, V. N.; Zhdankin, V. V. Tetrahedron 2010, 66, 5745-5752. doi:10.1016/j.tet.2010.04.046

60. Yakura, T.; Konishi, T. Synlett 2007, 765-768. doi:10.1055/s-2007-970758

61. Yakura, T.; Yamauchi, Y.; Tian, Y.; Omoto, M. Chem. Pharm. Bull. 2008, 56, 1632-1634. doi:10.1248/cpb.56.1632

62. Yakura, T.; Tian, Y.; Yamauchi, Y.; Omoto, M.; Konishi, T. Chem. Pharm. Bull. 2009, 57, 252-256. doi:10.1248/cpb.57.252

63. Yakura, T.; Omoto, M. Chem. Pharm. Bull. 2009, 57, 643-645. doi:10.1248/cpb.57.643

64. Yakura, T.; Omoto, M.; Yamauchi, Y.; Tian, Y.; Ozono, A. Tetrahedron 2010, 66, 5833-5840. doi:10.1016/j.tet.2010.04.124

65. Yakura, T.; Ozono, A. Adv. Synth. Catal. 2011, 353, 855-859. doi:10.1002/adsc.201100024

66. Nambu, H.; Shimokawa, I.; Fujiwara, T.; Yakura, T. Asian J. Org. Chem. 2016, 5, 486-489. doi:10.1002/ajoc.201600036

67. Yakura, T.; Yamada, A.; Noda, N.; Fujiwara, T.; Nambu, H. Asian J. Org. Chem. 2014, 3, 421-424. doi:10.1002/ajoc.201300279

68. The oxidation of $14 \mathrm{a}$ with 23 at $70{ }^{\circ} \mathrm{C}$ was also reported to be very slow [67].

69. The corresponding aldehyde remained even after the starting alcohols were completely oxidized (checked by TLC).

70. Ishihara and colleagues also suggested that the rate-determining step of their oxidations might be the regeneration of $\mathrm{I}(\mathrm{V})$ species [52].

\section{License and Terms}

This is an Open Access article under the terms of the Creative Commons Attribution License (http://creativecommons.org/licenses/by/4.0), which permits unrestricted use, distribution, and reproduction in any medium, provided the original work is properly cited.

The license is subject to the Beilstein Journal of Organic Chemistry terms and conditions: (https://www.beilstein-journals.org/bjoc)

The definitive version of this article is the electronic one which can be found at: doi:10.3762/bjoc. 14.82 